\title{
A construção da memória da Guerra Colonial em Os cus de Judas, de Lobo Antunes
}

\author{
The construction of the Colonial War memory in Os cus de Judas, of Lobo Antunes
}

\author{
LEONARDO VON PFEIL ROMMEL \\ Universidade Federal do Rio Grande do Sul
}

AlFEu SPAREMBERGER

Universidade Federal de Pelotas

\begin{abstract}
Resumo: O presente artigo analisa o romance Os cus de Judas, de autoria do escritor português António Lobo Antunes quanto à sua particularidade em estabelecer a construção de uma memória coletiva sobre a Guerra Colonial. Segundo romance do autor, publicado em 1979 em um contexto pós-colonial apenas quatro anos após a Revolução dos Cravos, a narrativa remete à abordagem da exploração da experiência do autor durante sua participação na Guerra Colonial, em Angola, no início da década de 70. Após a Revolução dos Cravos, em abril de 1974, a sociedade portuguesa tenta apagar o passado traumático ligado à guerra e ao Estado Novo a fim de iniciar um movimento de superação de seu passado problemático e aproximar-se da Europa. A produção ficcional apresenta-se como possibilidade de interpretação da dinâmica política e social existente na construção de um novo Portugal após a Guerra Colonial, a Revolução dos Cravos e a descolonização dos territórios ultramarinos. A literatura assume um papel de destaque no Portugal pós-colonial, pois almeja a construção de uma memória coletiva sobre os últimos capítulos do império português.
\end{abstract}

Palavras-chave: Os cus de Judas; Guerra Colonial; Memória; Pós-colonialismo

\begin{abstract}
The present article analyzes the novel Os cus de Judas, written by the portuguese writter António Lobo Antunes for their particularity to estabilish the construction of a collective memory about the Colonial War. Second novel of the author published in 1979 in a post-colonial context, just four years after the Carnation Revolution, the narrative refer to approach the exploration of the author's experience during his participation in the Colonial War in Angola, in the early 1970. After the Carnation Revolution in April 1974, the portuguese society tries to erase the traumatic past linked to the war and the Estado Novo to start a movement of overcoming his troubled past and move closer to Europe. The fictional production is presented as a possible interpretation of the dynamics political and social context in building a new Portugal after the Colonial War, the Carnation Revolution and decolonization of overseas territories. The literature plays an important role in Portugal post-colonial since aims to build a collective memory of the last chapter of the portuguese empire.
\end{abstract}

Keywords: Os cus de Judas; Colonial War; Memory; Post-colonialism

O presente artigo analisa o romance $O$ s cus de Judas, de autoria do escritor português António Lobo Antunes quanto à sua particularidade em estabelecer a construção de uma memória coletiva sobre a Guerra Colonial. Segundo romance do autor, publicado em 1979 em um contexto pós-colonial apenas quatro anos após a Revolução dos Cravos, a narrativa remete à abordagem da exploração da experiência do autor durante sua participação na Guerra Colonial, em Angola, no início da década de 70.
Os cus de Judas faz parte do primeiro ciclo da produção literária do escritor português, denominado pela crítica, e pelo próprio Lobo Antunes, de Trilogia da aprendizagem, conjunto de três romances autobiográficos formado por Memória de elefante (1979), Os cus de Judas (1979) e Conhecimento do inferno (1980), que se apoiam na experiência do escritor na Guerra Colonial e tratam do traumático processo de regresso e readaptação dos ex-combatentes no período pós-guerra. 
Entre 1961 e 1974 Portugal manteve uma relação extremamente conflituosa com suas colônias africanas. A Guerra Colonial produziu-se em um contexto em que os países africanos buscavam sua independência do colonialismo europeu, que perdurava no continente há séculos. Estima-se que, a fim de combater o movimento de desintegração do corpo físico do império, Portugal tenha enviado para os campos de batalha no continente africano cerca de um milhão de soldados. Sendo assim, a guerra foi responsável por mobilizar uma grande parcela da sociedade portuguesa, que esteve envolvida direta ou indiretamente no conflito e em suas consequências.

A Revolução dos Cravos, em abril de 1974, assinala em Portugal o final do período imperial, marcado pela ditadura salazarista e pela Guerra Colonial nos territórios ultramarinos. Após a Revolução, o governo revolucionário imediatamente dá início ao processo de independência e descolonização, almejando, assim, afastar-se do passado imperialista e isolacionista defendido duramente por Salazar durante as quatro décadas em que esteve no poder.

A Guerra Colonial, a Revolução dos Cravos, a queda do Estado Novo e o processo de descolonização da África, constituem-se uma ruptura na sociedade e na memória coletiva nacional que, durante cerca de cinco séculos, baseou-se em uma visão nacionalista do passado imperialista português. Como aponta Jorge Manuel da Costa (2013), após abril de 1974 Portugal vê-se confrontado com o desmoronar da grandiosidade imperial, conceito muito valorizado pelo discurso oficial do governo ao longo da História.

Liberto de um longo período de relacionamento problemático com a sua memória, instilado ditatorialmente por uma discursividade eufórica dos feitos bélicos e expansionistas do seu passado histórico, o Portugal de Abril de 74 vê-se confrontado com o desmoronar da grandiosidade imperial que, até esse ponto, havia assinalado o discurso identitário e de memória que oficialmente vigorava no seu espaço interno (COSTA, 2013, p.11).

Após o esfacelamento do império colonial, a sociedade portuguesa mergulhou em um estado de amnésia coletiva como única forma de contornar os eventos traumáticos ocasionados pela Guerra e pela dinâmica político-social da Revolução e da descolonização. O movimento de apagamento da contemporaneidade, iniciado após abril de 1974, foi responsável por criar uma espécie de estado de exceção, que impedia a criação de uma memória coletiva sobre a contemporaneidade e sobre o processo de construção de uma História pós-colonial.

Portugal, historicamente possuidor de colônias e territórios ao redor do planeta, país sempre autoconcebido pelo discurso estatal como grande potência imperial, capaz de fazer frente aos vizinhos europeus, sofre uma ruptura em sua identidade e representação histórica após a Revolução e a descolonização da África. Segundo Costa (2013), a perda dos territórios africanos constituiu-se um traumático abalo na autorepresentação nacional, o que, consequentemente, leva o país a vivenciar um processo de fechamento sobre si próprio, como tentativa de expurgar a memória incômoda da guerra e do fracasso imperialista.

Após abril de 1974, a estratégia de silenciamento nacional e a tentativa de apagamento do traumático passado recente, constituem-se uma alternativa de manutenção por parte do governo revolucionário, das condições necessárias para reerguer a nação e mantê-la coesa no objetivo de construção das bases de uma nova História, quando se poderia vislumbrar o futuro e a ultrapassagem do passado imperialista e ditatorial.

$\mathrm{Na}$ visão de Costa (2013, p. 141), o esquecimento do passado recente seria "a condição fundamental para que a metáfora de perpétuo movimento da nação pudesse ser novamente reiniciada", abandonando o passado imperialista e isolacionista construído pela retórica do Estado Novo e aproximando-se, assim, dos vizinhos da Europa, como forma de alterar a imagem de Portugal e defender a sua modernização política e econômica.

Quanto ao Portugal de Abril e à nova imagem que luta por concretizar, o que se obtém é, no fundo, um modelo identitário que encontra na fuga seletiva ao passado a estratégia preferencial para a manutenção do caráter ideal de que se pretende revestir. Tendencialmente direcionado para o desvio sistemático de situações ou eventos que levantem a ponta do véu traumático e do recente terror do fracasso nacional (o mesmo será dizer, que remetam, ainda que por instantes, o país para um plano de eventual autoquestionação) (COSTA, 2013, p. 3)

Norberto do Vale Cardoso (2011, p. 160) destaca que “essa eliminação da História colonial é um mecanismo do novo tempo democrático português para superar o lado negro da sua História", e que o desejo de reaproximação e integração do país ao continente europeu, por parte do novo governo, seria uma forma de ruptura com o passado ditatorial, isolacionista e opressivo alimentado pelo regime salazarista.

Como aponta Eduardo Lourenço (2013), em seguida à Revolução dos Cravos a sociedade portuguesa tentou destruir a memória da ditadura salazarista, promovendo um processo de distanciamento e deslocação da identificação nacional com a imagem do Estado Novo e do colonialismo na África, condenado diversas vezes pela Organização das Nações Unidas. A imagem do antigo regime expunha as fraquezas de Portugal e impedia a concretização de uma redemocratização e uma 
descolonização rápida e exemplar na visão das Forças Armadas após assumirem o poder.

A primeira fase da revolução caracterizou-se pela tentativa frenética de deslocar a imagem fascista da realidade nacional presente e passada, de destruir pela raiz o que se supunha mera pintura superficial do país, que, lavado e expurgado dos seus demónios passageiros, poria à mostra as suas virtualidades [...] (sic) (LOURENÇO, 2013, p. 50).

Segundo Ribeiro (2004, p. 248), o regime salazarista buscava sempre ocultar os acontecimentos da Guerra Colonial, como tentativa de manter o estado de normalidade da população da metrópole na Europa. Ainda, segundo a autora, a consequente ocultação da guerra, mesmo pós25 de abril, não se tratava de uma vontade autoritária, "mas sim uma incapacidade de avaliação das condições reais para lidar com tão dolorosa e explosiva herança e imagem de um antigo poder que se queria esquecer". O silêncio historiográfico, político e social sobre o passado recente, que caracterizou a sociedade portuguesa pósabril de 1974, deve-se aos naturais mecanismos de recusa, denegação e luto perante o trauma da guerra e da memória opressiva do antigo regime.

Cardoso (2011, p. 172) menciona que o Estado Novo entendia que a Guerra Colonial poderia pôr em risco a paz social, por isso "a guerra se viu transferida para uma 'lonjura' como forma de a distanciar da metrópole e reduzir o seu impacto na sociedade portuguesa", e que a única forma encontrada pelo aparelho estatal de a controlar, foi preenchê-la de um sentido que a englobasse na falsa retórica de missão civilizadora da pátria portuguesa.

Roberto Vecchi (2010) refere que a Guerra Colonial punha em jogo a pseudomemória imperialista construída pelo Estado Novo, e a veiculação de notícias pela imprensa e a sua presença na metrópole europeia apresentavam-se como perigoso obstáculo para a manutenção da continuidade do regime salazarista. Vecchi (2010) salienta, ainda, que nos conflitos no continente africano não estavam em jogo somente os espaços e territórios do império, mas, principalmente, os cinco séculos de História de Portugal.

(...) em jogo estava algo de mais complexo do que a defesa do espaço colonial: como declamava a retórica do regime salazarista, em jogo estavam cinco séculos da História de Portugal, cinco séculos de colonização ou, como ficou depois da maquilhagem retórica da revisão constitucional de 1951, cinco séculos de relações entre povos e culturas diferentes (VECCHI, 2010, p. 96).

A Guerra Colonial pode ser entendida como uma espécie de estado de exceção na História imperial portuguesa, pois, após o início dos movimentos de libertação dos países africanos, Portugal viu-se obrigado a combater a si próprio, a fim de que pudesse evitar o desmembramento do corpo político da nação, uma vez que os territórios ultramarinos compunham e participavam ativamente do processo de construção do imaginário e da identidade nacional.

Ribeiro (2004) adota uma visão bastante semelhante no que se refere à Guerra Colonial; segundo a autora, a guerra é responsável por efetivar uma espécie de movimento de tensão na identidade nacional. Como aponta ainda a autora, a guerra marca o início do processo de desterritorialização e desmembramento do império colonial português, que o fez regressar para junto da Europa, o que pode ser considerado um fenômeno basicamente novo e traumático para a História de um país mundialmente reconhecido como essencialmente imperialista e colonizador.

Em artigo publicado no Diário de Notícias em 1984, dez anos após a Revolução dos Cravos, Eduardo Lourenço demonstra-se surpreso com o fato de a História recente de Portugal, o colonialismo e a Guerra Colonial na África não terem dado origem a manifestações culturais ou reflexões mais aprofundadas nas áreas da historiografia e da política na sociedade pós- 25 de abril.

À aproblematização voluntária do antigo regime sucedeu uma espécie de insólita ocultação acerca dos avatares da última fase da nossa velha - pensar-se-ia capital - aventura colonial. Nem documentários, nem filmes, nem "livros brancos" sobre a nossa história recente em África contribuíram com qualquer explicação ou simples informação sobre o que, para já, conduziu em casa europeia à liquidação de um regime antidemocrático e, fora dela, ao fim de um império (sic) (LOURENÇO, 1984 apud RIBEIRO, 2004, p. 246).

Ainda de acordo com Eduardo Lourenço (1984 apud Ribeiro 2004), em relação ao fenômeno de silenciamento social e cultural sobre o passado recente iniciado a partir do movimento de Revolução e redemocratização em abril de 1974, existia no país uma espécie de "insólita ocultação", que tornava interditos os capítulos finais do império colonial português, como a queda da ditadura do Estado Novo, a Guerra Colonial e o processo de descolonização dos territórios ultramarinos.

Jorge Manuel da Costa (2013, p. 147) afirma que, já no final da década de 80, são ainda extremamente reduzidas as propostas discursivas de abordagem do recente passado imperial português, sendo a sociedade e a cultura ainda dominadas por uma ambiguidade de posicionamentos emanada pela esfera estatal, que entendia a alternativa do esquecimento e da ocultação do passado imperialista e opressivo da nação como uma "arma preferencial para 
assegurar a criação ilusória de um perpétuo movimento nacional".

Dado o traumático rompimento da linearidade discursiva da História portuguesa pós-abril de 1974, que esmagou o presente sob o peso de um passado monumentalizado pela memória imperialista, a literatura assumiu-se como um dos únicos discursos capazes de produzir uma reconstituição histórica do traumático passado nacional, marcado pela Guerra Colonial e pela queda do modelo imperialista do Estado Novo.

Vecchi (2010) comenta que a literatura surgida após a Revolução dos Cravos, que se destina a tematizar a Guerra Colonial, ganha corpo em um vazio historiográfico, e atende à necessidade social de reler o passado imediato, de ler e escrever a História recente, interdita e silenciada pela repressão estatal. Mediante a mobilização do testemunho e da subjetividade, a literatura assume um papel de combate à amnésia nacional, recuperando o direito social de produzir e comunicar a sua memória individual e coletiva.

\begin{abstract}
A prática da literatura como anamnésia nacional surge copiosamente das estações de abertura política, restabelecimento das liberdades civis, com a explosão da subjetividade da recordação, a necessidade presente de reler o passado imediato, não tanto - ou não apenas - para procurar informações inéditas, visto que directa ou indirectamente os acontecimentos eram de qualquer modo conhecidos, mas para readquirir a sujbectividade, a protagonização de escrever ou de ler em primeira pessoa a história interdita, recuperar o direito de comunicar a memória e a experiência, também singular (VECCHI, 2010, p. 60).
\end{abstract}

A abordagem da Guerra Colonial torna a literatura uma espécie de discurso de exceção, responsável por romper com a aparente linearidade e horizontalidade do discurso historiográfico português. Por meio da literatura, acontecimentos traumáticos e interditos pela memória ativa da repressão salazarista são identificados por entre os despojos do desabamento do império colonial português, possibilitando, assim, um espaço de reflexão sobre o Portugal contemporâneo e suas fraturas históricas.

A literatura portuguesa, surgida no momento de transição entre um tempo imperial/pós-imperial, busca efetivar-se como uma espécie de documento, capaz de relatar esta fase de intensas mudanças da sociedade e da cultura nacional. Como assevera Gomes (1993, p. 84), "essa busca de verismo e do histórico fundamenta-se pelo desejo de transformação do romance num documento de uma era de convulsões e de modificações substanciais na sociedade portuguesa", como a Guerra Colonial e a Revolução dos Cravos.
Como se pode observar, num período muito curto de tempo, a realidade portuguesa sofreu profundas mutações - a Revolução, com suas consequências imprevisíveis, imprimirá um dinamismo sem precedentes nas relações sociais e na vida cultural do país. O resultado disso é a sucessão vertiginosa das ideologias, dos modos de comportamento, dos modos de atuação política, o que implicará, às vezes, descompassos entre os acontecimentos e o olhar que tenta registrá-los. [...]. Se os jornais - formas não ficcionais de abordar a realidade - se contentam com a fixação do efêmero e a consequente diluição da notícia dentro do dinamismo da história, o romance, que aspira a uma transcendência, a uma atemporalidade, deve se servir de outros mecanismos, que não a pretensa objetividade factual, para não sucumbir ao desenrolar do tempo (GOMES, 1993, p. 84).

O discurso ficcional, no Portugal pós-abril de 1974, apresenta-se como possibilidade de análise do contexto social e da dinâmica da evolução do país promovida pela transição do processo revolucionário. $\mathrm{O}$ romance surge como uma forma de enfrentamento desse processo dinâmico iniciado com a Revolução, que via na substituição e no esquecimento de um período histórico e de um modelo político-social ultrapassado e opressivo, a única forma de evolução. A ficção se assume como tentativa de resgate dos últimos capítulos do império português, como a Guerra Colonial e a Revolução dos Cravos.

Em algumas circunstâncias históricas, a literatura torna-se instrumento de elaboração e recomposição de traumas e de lutas coletivas, estabelecendo uma íntima associação com a escrita da história. Passa, então, a suprir seus silenciamentos e rupturas em busca da representação, com maior impressão de totalidade, dos acontecimentos traumáticos e interditos de uma determinada coletividade, como foi o caso da Guerra Colonial em Portugal.

[...] existem circunstâncias históricas nas quais a literatura se reveste de funções ulteriores em relação àquelas que tradicionalmente desempenha: tornase instrumento de elaboração, e de recomposição, diríamos quase que terapêutica de traumas e de lutas colectivas, estabelece uma estreita aliança com a escrita da história e tenta recompor, umas vezes ingenuamente, outras em modo um pouco desencantado, fracturas, descontinuidades com o passado, de cada um e de todos, fornecendo as cifras para a compreensão, possivelmente aquela que melhor dê uma impressão de totalidade ao acontecido (VECCHI, 2010, p.60).

A literatura apresenta-se, assim, como um discurso que possibilita o questionamento da história e dos acontecimentos do Portugal contemporâneo. O discurso artístico visa a recompor e explorar experiências e traumas 
que afetaram a sociedade portuguesa durante o período de transição imperial/pós-imperial, auxiliando na construção de uma memória coletiva sobre os últimos capítulos do império português.

Apontado pela crítica como um dos primeiros testemunhos literários sobre a Guerra Colonial na África, Os cus de Judas apresenta-se organizado sob uma estrutura dividida em 23 capítulos, nomeados de acordo com as letras do alfabeto português, de A a Z, cuja organização pode ser considerada uma espécie de "alfabeto da agonia". De acordo com Seixo (2002, p. 42), a estruturação do romance, segundo a ordem do alfabeto, estabelece "um exame crítico e emocional da guerra em Angola de A a Z".

Na visão de Norberto Cardoso (2011), o romance, por intermédio de sua violenta narrativa, realiza uma certa reconstrução do mundo português de $\mathrm{A}$ a Z, apresentandose como uma espécie de manual ao avesso, no qual Lobo Antunes executa um processo de requestionamento da vida e da sociedade portuguesa no período pósRevolução dos Cravos, abordando questões traumáticas para a coletividade nacional, como a violência e os duros efeitos da Guerra sobre os combatentes, a repressão do Estado Novo e o processo de desconstrução do império português.

Em Os cus de Judas temos como protagonista do romance um médico psiquiatra recém-retornado da Guerra Colonial em Angola, onde exerceu a função de tenente médico do Exército português durante cerca de dois anos. Por meio de uma intensa narrativa em primeira pessoa, o protagonista extravasa suas memórias, angústias e lembranças, muitas vezes fragmentadas, do passado traumático da guerra, tecendo relações com a infância e lançando uma forte crítica à sociedade burguesa e ao sistema imperialista português.

Lobo Antunes produz uma narrativa em que, utilizando sua experiência pessoal como combatente em Angola no início da década de 70, constrói, mediante o discurso literário, uma ácida crítica ao regime salazarista do Estado Novo, trazendo para a sociedade o drama dos soldados retornados que, muitas vezes, tinham sua vida pessoal fragmentada, e toda a brutalidade que o sistema colonial impunha ao povo das colônias africanas.

$O$ protagonista vive às margens da sociedade, uma vez que, ao retornar da guerra, jamais conseguiu restabelecer as suas relações sociais, familiares e profissionais. Encontrase divorciado da esposa e incompreendido pela família, que sempre esperou que sua participação no Exército o tornasse um homem de verdade, digno de representar toda a tradição ilustre e guerreira da família. Quanto ao exercício da medicina, sua rotina desregrada, conduzida pela insônia e pelo constante consumo de álcool, que o ajuda a enfrentar a jornada da agonia da noite, afasta-o totalmente dos compromissos, e sua credibilidade, junto aos colegas e pacientes, não é das melhores.

A participação na guerra serviria como uma espécie de metamorfose, que seria responsável por transformar o ainda jovem e inexperiente médico em um "verdadeiro homem", a fim de que pudesse se tornar um representante digno e verídico da tradição familiar, portador das virtudes de seus gloriosos antepassados, ironicamente designados pelo narrador como "furibundos generais" participantes de "gloriosos combates de gamão de bilhar", falecidos muito antes do seu nascimento.

O embarque do protagonista para a Guerra Colonial no interior de Angola é acompanhado com júbilo e orgulho pelos seus familiares, sendo por ele descrito como um triste e cruel quadro da inoperância e submissão sociais perante os efeitos da opressão da ditadura comandada por Salazar, que revestia a guerra de um caráter de missão humanitária e nacionalista, que visava a extinguir a atividade terrorista nas colônias.

De modo que quando embarquei para Angola, a bordo de um navio cheio de tropas, para me tornar finalmente homem, a tribo, agradecida ao Governo que me possibilitava, grátis, uma tal metamorfose, compareceu em peso no cais, consentindo, num arroubo de fervor patriótico, ser acotovelada por uma multidão agitada e anónima semelhante à do quadro da guilhotina, que ali vinha assistir, impotente, à sua própria morte (ANTUNES, 2009, p. 14).

No constante processo de rememoração do passado, percebe-se que o protagonista se confronta com as lembranças da infância e com a insistência e pressão dos familiares para que ele cumprisse as normas impostas pela sociedade burguesa. Durante toda a sua formação as suas escolhas nunca foram realmente individuais; tudo foi sempre condicionado e imposto pela família, desde a escolha da profissão da Medicina, que está ligada ao pai, também médico, e também a participação na Guerra Colonial, uma vez que eram sempre muito valorizados os antepassados guerreiros e seus feitos quase que heroicos.

A imagem de um ser fragmentado, após cumprir com todas as suas obrigações e perseguir os modelos impostos pela família e sociedade portuguesa, contrasta com outra, de que se estivesse vivendo em Portugal demasiadamente à sombra de um passado opressivo, cujo resultado, ao longo do tempo, encaminhou o país a uma posição periférica e atrasada em razão do fechamento promovido pela máquina fascista do Estado Novo.

Maria José, a mulher com quem o protagonista se encontra em um bar, ouve-lhe com atenção e interesse, mas a seu respeito o leitor não tem acesso, sendo o seu nome mencionado em uma única oportunidade no decorrer de todo o romance. A personagem desempenha uma função 
praticamente anônima, servindo de confidente, que ajuda o protagonista na dolorosa travessia da noite, quando cotidianamente é acometido pela depressão e melancolia após a separação da esposa e ao ser assombrado pelas lembranças da morte e do sofrimento na guerra.

Cardoso (2011) comenta que o silêncio da interlocutora trata-se de uma poderosa forma de discurso sobre a Guerra Colonial e representa a metáfora de uma sociedade assombrada pela memória da repressão salazarista, quando o silêncio era a norma. Segundo o autor, é por meio do seu silêncio que a interlocutora concebe sentido ao discurso do protagonista, sendo, assim, responsável por potencializar $\mathrm{o}$ violento relato do narrador.

$\mathrm{Na}$ narrativa de Os cus de Judas, Lobo Antunes contempla o absurdo da guerra, a violência e a dominação imposta não somente aos africanos, mas também aos próprios combatentes portugueses. Esses eram jovens pertencentes a uma geração que foi arrancada de seus sonhos pessoais, afastada dos familiares e de seu país de origem para lutar contra um povo já massacrado pela pobreza e pela desigualdade gerada pelo sistema colonial português, em nome de um ideal ultrapassado, valorizado pelo peso da tradição histórica e totalmente contrário aos direitos básicos da humanidade.

De acordo com Cardoso (2011, p.222), "Judas é um romance que coloca em causa a verdade histórica, instituída por quem não a viveu", inscrevendo-se como um romance que indaga as várias verdades sobre a guerra, a ditadura e a Revolução. A narrativa é responsável por colocar diretamente em causa a História de Portugal, ao abordar acontecimentos traumáticos para a sociedade, trazendo para debate a guerra e suas consequências.

Porque camandro é que não se fala nisto? Começo a pensar que o milhão e quinhentos mil homens que passaram por África não existiram e lhe estou contando uma espécie de romance de mau gosto impossível de acreditar, com que a comovo a fim de conseguir mais depressa (um terço de peleio, um terço de álcool, um terço de ternura) que você veja nascer comigo a manhã na claridade azul pálida que fura as persianas e sobe dos lençóis (ANTUNES, 2010, p. 65).

Percebe-se nesta passagem da narrativa que o médico protagonista questiona o fenômeno da amnésia coletiva que tomou conta da sociedade portuguesa após a Revolução dos Cravos. Durante a conversa com sua companheira, ele compara a sua narração dos fatos a um romance criado, em que todo o absurdo da guerra parece ter sido inventado e não passa de uma ficção de mau gosto que ele conta a fim de que consiga atrair sua atenção e compaixão.

Os cus de Judas assume a forma de uma obra literária que busca trazer à tona e especular o alheamento e o silêncio que o próprio país mantinha diante da Guerra Colonial e do movimento revolucionário. Revela, ainda, a traumática situação dos soldados portugueses que, muitas vezes, regressavam traumatizados dos campos de batalha e acabavam, assim, estigmatizados pela sociedade portuguesa redemocratizada, uma vez que sua imagem encontrava-se ligada à memória da ditadura salazarista.

Segundo Cardoso (2011), o sujeito que participou da guerra, ao tomar consciência da traição promovida pela família e pelo Estado português, e mediante os incontornáveis traumas da violência, invariavelmente entra em um processo de autodestruição e gradativo afastamento social e familiar. A geração de soldados retornados da guerra é estigmatizada e excluída pela sociedade e temida pelo Estado, pois seus corpos estão marcados pela experiência destruidora da guerra e pela melancolia e resignação de terem presenciado o absurdo e empobrecedor resultado da valorização e da manutenção do colonialismo na África.

Cardoso (2011, p. 221) ressalta ainda, que "a geração que fez a guerra é, assim, vista pela sociedade portuguesa já democratizada como culpada pelas formas mais duras de Portugal ter exercido o colonialismo, sendo muitas vezes associada ao próprio regime". Em outra passagem, o autor afirma que "essa geração, que vivia já um vácuo de convicções, vê-se atomizada aquando do regresso a casa. Esta seria a dispersão de um capital colectivo temido pelo Estado" (p.119).

O título do romance, além de remeter à lonjura e ao isolamento geográfico que os combatentes enfrentavam ao serem enviados para a guerra no continente africano, direciona-se também a Judas, personagem bíblico conhecido pela traição, por entregar Jesus aos seus perseguidores, condenando-o à sentença de morte em troca de benefícios irrelevantes. Essa metáfora utilizada por Lobo Antunes transmite a ideia da traição, sendo o soldado português o sujeito que seguiu os ensinamentos de sua pátria, mas que, no decorrer da vida, se encontra marginalizado, entregue a um tempo pós-colonial no qual não é aceito, por ser ele a memória viva de um tempo marcado pelos traumas e pela opressão da guerra e do fascismo do Estado Novo, dos quais ele próprio é igualmente uma vítima.

Cardoso (2011) constata que o soldado antuniano, principalmente em Os cus de Judas, encontra-se em uma posição ambígua ante a sua sociedade, pois ele acaba por ser tomado como um "outro", alguém que, após cumprir suas funções a mando do Estado, se vê marginalizado, uma vez que não mais encontra espaço no imaginário coletivo. Além de ser ícone de um imperialismo que se prolongou por demasiado tempo, causando graves rupturas na sociedade, ele é portador do estigma da derrota, da perda das colônias. Ele representa os dois lados da moeda - 
aquele que defendeu a pátria, mas que ressurge trazendo o sentido da derrota antiépica.

Portanto, compreender a identidade do "soldado antuniano" será compreender outras identidades dentro da obra do autor. Em certa medida, podemos verificar que essa identidade se liga ao título do seu segundo romance publicado, Os cus de Judas. Referimo-nos aqui à figura de Judas, personagem bíblica à qual se apoia a imagem da "traição". Daqui retiraremos a ilação de que o soldado português acabou por ser um outro, "um Judas", aquele que estará numa "portagiratória", ou seja, que será ambos os lados e nenhum, algures entre a traição e a exclusão (CARDOSO, 2011, p. 30).

Seixo (2002, p.55) comenta que a questão da identidade do médico protagonista se espraia para questões de "personalidade, de profissão, de família, de identificação amorosa, de terra, de país" e liga-se ao contexto pós-colonial da narrativa. Após o regresso de Angola, o ex-combatente não mais consegue encontrar espaço nesse "novo" tempo em que seu país está inserido, e que ainda busca inserir-se, à custa da ocultação e da superação do passado recente.

Ribeiro (2004) salienta que o conceito de traição, aludido pelo título do romance, recai sobre a figura do protagonista de forma dupla, uma vez que ele é alguém que "traiu" o sistema ditatorial, alimentado pelo Estado Novo, ao regressar portador de uma memória incômoda - a perda dos territórios ultramarinos. O médico protagonista manifesta, então, de forma ambígua, repulsa e ódio pelo governo de seu país e simpatia pelo ímpeto libertador dos africanos, mas que ao ser submetido à violência da guerra e não mais conseguir reentrar na centralidade europeia, sente-se traído e vitimado pela família e pela máquina estatal, que lhe orientaram e encaminharam para a África.

O narrador-personagem não se coloca em nenhum dos espaços, ainda que por simpatia e solidariedade de vitimização pareça estar com os guerrilheiros, mas integrado na estrutura que os combate e, à parte pequenos gestos de raiva e fúria mais ou menos inconsequentes, nada fazendo para a mudar, o conceito de traição recai sobre ele de forma dupla: ele é, depois dos cus de Judas, um traidor (um Judas) em relação aos valores em que tinha sido educado e do Estado que o seu uniforme militar representa, mas apresenta-se sobretudo como vítima de uma traição da família e do Estado que o conduziram a um engano (RIBEIRO, 2004, p. 280).

A posição ambígua do protagonista em relação à guerra e ao seu país destaca-se, também, pelo fato de, apesar de não se identificar com a causa colonialista portuguesa e simpatizar com os africanos, ter de desempenhar a função de médico. No exercício de sua função, ele é o responsável por, metaforicamente, manter em funcionamento o corpo físico do Estado, representado pela figura dos combatentes, seus companheiros na antagônica experiência da "aprendizagem da agonia". Cabe a ele o papel de consertar os corpos dilacerados pela violência da guerra, sendo o responsável direto por salvar suas vidas ou assistir seu regresso a Lisboa em caixões de chumbo nos porões dos navios.

A cada ferido de emboscada ou de mina a mesma pergunta aflita me ocorria, a mim, filho da Mocidade Portuguesa, das Novidades e do Debate, sobrinho de catequistas e íntimo da Sagrada Família que nos visitava a domicílio numa redoma de vidro, empurrado para aquele espanto de pólvora numa imensa surpresa: são os guerrilheiros ou Lisboa que nos assassinam, Lisboa, os americanos, os russos, os chineses, o caralho da puta que os pariu combinados para nos foderem os cornos em nome de interesses que me escapam, quem me enfiou sem aviso neste cu de Judas de pó vermelho e de areia, a jogar as damas com o capitão idoso saído de sargento que cheirava a menopausa de escriturário resignado e sofria do azedume crónico da colite, quem me decifra o absurdo disto, as cartas que recebo e me falam de um mundo que a lonjura tornou estrangeiro e irreal, os calendários que risco de cruzes a contar os dias que me separam do regresso e apenas achando à minha frente um túnel infindável de meses, um escuro túnel de meses [...] (ANTUNES, 2010, p. 39-40).

Nesta passagem pode-se perceber o sentimento de inconformidade do protagonista ao se encontrar em uma guerra, na qual diariamente via morrer seus companheiros, muitos deles jovens iguais a ele, a quem o regime ditatorial obrigou a colaborar a fim de manter ilusoriamente a grandiosidade de Portugal. Percebe-se novamente a crítica às origens burguesas que, desde a sua infância, mostrava-se muito presente no seu ambiente familiar.

A experiência da guerra apresenta-se decisiva no processo de desestruturação do corpo físico e social do protagonista, que, após o retorno, é impedido, pelos traumas e vivências extremas a que foi submetido no continente africano, de reatar o ritmo de sua vida, que invariavelmente assume um prolongamento do "inferno" e de todo o sofrimento e opressão da guerra.

Quem veio aqui não consegue voltar o mesmo, explicava eu ao capitão de óculos moles e dedos membranosos colocando delicadamente no tabuleiro, em gestos de ourives, as peças de xadrez, cada um de nós, os vivos, tem várias pernas a menos, vários braços a menos, vários metros de intestino a menos, quando se amputou a coxa gangrenada ao guerrilheiro do MPLA 
apanhado no Mussuma os soldados tiraram o retrato com ela num orgulho de troféu, a guerra tornou-nos em bichos, percebe, bichos cruéis e estúpidos ensinados a matar [...], o mundo-que-o-português-criou são estes luchazes côncavos de fome que não nos entendem a língua, a doença do sono, o paludismo, a amibíase, a miséria [...]. (ANTUNES, 2009, p. 123).

A guerra é responsável por uma espécie de metamorfose, um movimento de desintegração e desumanização, que transforma os combatentes em "animais", cujos gestos se revestem de crueldade contra o povo africano. O império, o "mundo-que-o-portuguêscriou", aos olhos do médico protagonista, não passa de uma terra destruída, repleta de fome, doenças e miséria. Os ideais, que historicamente embasaram a expansão portuguesa, são postos à prova na narrativa que averigua o produto final do imperialismo português.

Como aponta Ribeiro (2004, p. 270), por meio da guerra o protagonista percebe que aquele mundoque-o-português-criou, na verdade, não passa de um "espelho grotesco e excessivo da grande mentira da casa portuguesa". A imagem de grande império nacional, sustentada pela ditadura salazarista, começa a ruir após a Guerra Colonial, que põe em jogo a memória imperial portuguesa e conduz o país ao desmembramento forçado de seus territórios coloniais, outrora centros mantenedores da identidade nacional.

A guerra foi responsável por fazer com que o médico protagonista se sentisse "nu de raízes", repelido tanto pela África, continente a que nunca pertenceu mas que fora obrigado a visitar para combater seu ímpeto libertador, quanto pelo seu país, que, após a esquizofrênica e desumana experiência dos conflitos, já não o aceita, por ser ele o representante do passado ditatorial, estando marcado por um poder estatal que levou até às últimas consequências a manutenção do colonialismo como forma de afirmação econômica e política.

O medo de voltar ao meu país comprime-me o esófago, porque, entende, deixei de ter lugar fosse onde fosse [...]. Flutuo entre dois continentes que me repelem, nu de raízes, em busca de um espaço branco onde ancorar, e que pode ser, por exemplo, a cordilheira do seu corpo, um recôncavo, uma cova qualquer do seu corpo, para deitar, sabe como é, a minha esperança envergonhada. (ANTUNES, 2010, p. 182).

No momento do regresso da África, conforme o protagonista, os soldados retornados assumiram o aspecto de fantasmas que, pouco a pouco, se materializaram, e passaram a ocupar as ruas e os espaços da metrópole, trazendo consigo, na bagagem da memória, o inenarrável e o indizível absurdo da guerra. A Lisboa que o médico reencontra após o regresso definitivo de Angola, apresen- ta-se agora como uma cidade vertical, hostil e desprovida de humanidade, uma espécie de labirinto, por onde este Judas, encarcerado entre a vida perdida e o serviço militar cumprido, procura abrigo perante os traumas do passado.

Esse retorno, segundo o protagonista, assemelha-se a um "ressuscitar de Lázaro desnorteado, que reaprende penosamente o uso dos objectos e dos sons" (ANTUNES, 2010 , p. 195) e que precisa se readaptar à centralidade da vida urbana e às relações familiares e sociais, interrompidas com a fatídica viagem para a guerra na África. Em Lisboa, sua cidade natal, o ambiente tornase estrangeiro, e na imaginação do médico, habituado à África, lhe parece que os ambientes, tão distintos um do outro, são capazes de se interpenetrar, como se Angola tivesse lhe acompanhado Atlântico adiante.

Habituara-me demais ao silêncio e à solidão de Angola, e afigurava-se-me inimaginável que o capim não rompesse do alcatrão das avenidas os seus longos dedos verdes acerados pelas primeiras chuvas. Não existia nenhuma máquina de costura ferrugenta e avariada na casa dos meus pais, e o soba do Chiúme não me esperava na sala, a fitar, para lá da estante envidraçada dos livros, a vastidão, húmida de sapos e de lodo, da chana. Idêntico a uma criança quando nasce, contemplava, com órbitas redondas de surpresa, os semáforos, os cinemas, o contorno desequilibrado das praças, as melancólicas esplanadas dos cafés, e tudo se diria possuir, ao meu redor, uma carga de mistério que eu seria sempre incapaz de elucidar. De forma que encolhi a cabeça entre os ombros e curvei as omoplatas como as pessoas sem gabardina perante uma chuva inesperada, oferecendo o mínimo possível do meu corpo a um país que não entendia já, e embarafustei pelo janeiro da cidade. (ANTUNES, 2010, p. 195).

A sua casa, ambiente que deveria ser responsável por emanar segurança e conforto, assemelha-se agora a uma "espécie de jazigo, vazio e hirto" (ANTUNES, 2010, p. 125) após o retorno de Angola. Da mesma forma, a cidade é invadida pela guerra e por toda a sua pulsão de morte, desumanizando todas as pessoas, seres e objetos, e tornando-o um sujeito assombrado por fantasmas que insistem em persegui-lo, fazendo com que jamais consiga reconquistar a vida que tinha antes de visitar o "inferno" da guerra e da lá retornar aos pedaços.

Conforme Ribeiro (2004, p. 284), “a excessiva e neurótica imagem de África, com os seus cheiros de morte e estropiamento, projecta-se em tudo, bloqueando o futuro". A morte e a guerra instalam-se, confortavelmente, substituindo a antiga existência do protagonista em sua casa, em sua cidade e em suas relações amorosas. O cotidiano do médico protagonista torna-se agora um "mundo labiríntico e assumidamente marginal" (p.289), 
de onde o mundo, tido por ele como "normal" antes da experiência africana, afasta-se progressivamente, deixando-lhe desorientado, morador de uma casa vazia, preenchida tão somente pelos traumas e pela dor que carrega na memória.

O quimbo da Tia Teresa, cercado pelo odor doce dos pés de liamba e de tabaco, é talvez o único sítio que a guerra não logrou invadir do seu cheiro pestilento e cruel. Alastrou por Angola, a terra sacrificada e vermelha de Angola, alcançou Portugal a bordo dos barcos de militares que regressavam, desorientados e tontos, de um inferno de pólvora, insinuou-se na minha humilde cidade que os senhores de Lisboa mascararam de falsas pompas de cartolina, encontrei-a deitada no berço da minha filha como um gato, fitando-me com pupilas de maldade oblíqua, a mirar-me dos lençóis com a turva raiva invejosa [...]. A guerra propagou-se aos sorrisos das mulheres nos bares, sob as ampolas despolidas dos candeeiros que lhes multiplicam de sombras a curva indagadora dos narizes, turvou as bebidas de um gosto azedo de vingança, aguarda-nos no cinema, instalada no nosso lugar, vestida de preto como um notário viúvo a retirar do bolso do casaco o estojo de plástico dos óculos. Está aqui, nesta casa vazia, nos roupeiros desta casa vazia, grávida dos fetos moles da minhas cuecas, no geométrico espaço de trevas que as lâmpadas não alcançam nunca, está aqui e chama-me baixinho com a pálida voz ferida dos camaradas assassinados nas picadas de Ninda e de Chiúme (ANTUNES, 2010, p. 173).

Pela narrativa de Os cus de Judas, Lobo Antunes aborda a fatídica experiência da Guerra Colonial e seus traumáticos efeitos na sociedade portuguesa. $\mathrm{O}$ médico protagonista apresenta-se como o representante de uma geração de portugueses que foi vítima da opressão do regime salazarista, e que foi obrigada a combater em uma guerra a fim de manter a posse dos territórios ultramarinos na África. O romance emerge, assim, como um grito de revolta e de desabafo ante o antigo regime e à sua memória ainda ativa na sociedade no período pós-Revolução dos Cravos.

A literatura desempenha um papel fundamental no período pós-1974, pois se apresenta como alternativa para a construção de uma memória coletiva sobre o período de transição pós-colonial em Portugal. Com o discurso ficcional, a experiência da Guerra Colonial, que seria fatalmente apagada pelo movimento de evolução do país, é resguardada do esquecimento, simbolizada e transformada em linguagem.

Os cus de Judas atua como uma narrativa literária que auxilia na construção de uma memória coletiva sobre a Guerra Colonial, uma vez que o romance aborda um traumático capítulo da sociedade portuguesa. Em Lobo Antunes, a literatura serve como forma de dar vazão e comunicar os traumas da guerra e da opressão gerados sobre toda uma geração de portugueses. No Portugal póscolonial o discurso literário visa a suprir a impotência do discurso histórico diante da guerra e do processo de redemocratização, evitando, assim, que o passado recente do país caia no esquecimento.

\section{Referências}

ANTUNES, António Lobo. Os cus de Judas. Rio de Janeiro: Objetiva, 2010.

CARDOSO, Norberto do Vale. A mão-de-Judas: representações da Guerra Colonial em António Lobo Antunes. Lisboa: Texto Editores, 2011.

COSTA, Jorge Manuel de Almeida Gomes da. Para um estudo da memória e identidade portuguesa com António Lobo Antunes. 2013. $241 \mathrm{f}$. Tese (Doutorado em Letras - Literatura Comparada) - Faculdade de Letras, Centro Regional das Beiras, Universidade Católica Portuguesa, Lisboa, 2013.

GOMES, Álvaro Cardoso. A voz itinerante. Ensaio sobre o romance português contemporâneo. São Paulo: Ed. da Universidade de São Paulo, 1993.

LOURENÇO, Eduardo. O labirinto da saudade. Lisboa: Dom Quixote, 2013.

RIBEIRO, Margarida Calafate. Uma história de regressos: império, guerra colonial e pós-colonialismo. Porto: Afrontamento, 2004.

SEIXO, Maria Alzira. Os romances de António Lobo Antunes. Lisboa: Dom Quixote, 2002.

VECCHI, Roberto. Excepção atlântica: pensar a literatura da Guerra Colonial. Porto: Afrontamento, 2010.

Recebido: 12 de setembro de 2016 Aprovado: 29 de maio de 2017 Contato: 1vpfeil@hotmail.com berger9889@gmail.com 